\title{
Barriers and Opportunities in Recalls Management at the Health Care Provider Level
}

\author{
Angélica Burbano Collazos «, Luisa Fernanda Durán Gutiérrez, José Antonio García Pretelt, \\ Diego Mauricio Ojeda Navia
}

Industrial Engineering Department, Universidad Icesi, Cali, Colombia

\begin{abstract}
One of the operational risks to which a Health Care Provider (HCP) is exposed is the receiving and use of products such as pharmaceuticals and medical devices that could become subject to a health alert. This patient safety issue has to be managed in order to prevent and mitigate adverse events at the last echelon of the supply chain. This article aims to expose a characterization of the alerts response process at the HCP level based on a review of the literature. Additionally, local regulations, strengths and weaknesses were identified. Finally, the study allowed for the identification of the principal opportunities and barriers that should be addressed in order to integrate the recall management process within and outside the HCP. Among these opportunities is traceability along the supply chain, and among the barriers is the high investment in the technology required to facilitate supply chain integration.
\end{abstract}

Keywords - Health Care Provider, alert, recall, traceability, supply chain.

\section{BARRERAS Y OPORTUNIDADES EN LA GESTIÓN DE RETIRO DE PRODUCTOS FARMACÉUTICOS EN LAS INSTITUCIONES PROVEEDORAS DE SALUD}

Resumen-Uno de los riesgos operacionales a los que está expuesto un Proveedor de Atención Médica (HCP por sus siglas en inglés) es la recepción y uso de productos farmacéuticos y dispositivos médicos que podrían estar sujetos a una alerta de salud. Este problema de seguridad del paciente tiene que ser manejado con el fin de prevenir y mitigar los eventos adversos en el último escalón de la cadena de suministro. Este artículo pretende exponer una caracterización del proceso de respuesta de alertas desde el HCP basado en una revisión de la literatura. Además, se identificaron la normativa local, fortalezas y debilidades. Finalmente, el estudio permitió identificar la principales oportunidades y barreras que se deben abordar para integrar el proceso de gestión de retiro de productos dentro y fuera del HCP. Entre estas oportunidades está la trazabilidad a lo largo de la cadena de suministro, y entre las barreras está la alta inversión en la tecnología requerida para facilitar la integración de la cadena de suministro.

Palabras clave-Proveedor de atención médica, alerta, retiro, trazabilidad, cadena de suministro. 


\section{BARREIRAS E OPORTUNIDADES NA GESTÃo DE RECALL DO PRODUTO NO NíVEL do Provedor de Cuidado da Saúde}

Resumo-Um dos riscos operacionais aos que está exposto um Provedor de Atenção Médica (HCP) é a recepção e o uso de produtos como produtos farmacêuticos e dispositivos médicos que poderiam estar sujeitos a uma alerta de saúde. Este problema de segurança do paciente tem que ser manejado com o fim de prevenir e mitigar os eventos adversos no último degrau da cadeia de fornecimento. Este artigo pretende expor uma caracterização do processo de resposta de alertas a nível do HCP baseado numa revisão da literatura. Ademais, identificaram-se as regulações locais, fortalezas e debilidades. Finalmente, o estudo permitiu identificar as principais oportunidades e barreiras que devem-se abordar para integrar o processo de gestão de produtos dentro e fora do HCP. Entre estas oportunidades está a traçabilidade ao longo da cadeia de fornecimento, e entre as barreiras está o alto investimento na tecnologia requerida para facilitar a integração da cadeia de fornecimento.

Palavras-chave — Provedor de atenção de saúde, alerta, recall do produto, traçabilidade, corrente de fornecimento.

\section{INTRODUCTION}

$\mathrm{I}^{\mathrm{n}}$ $n$ the context of total quality management, risk management allows for the identification of possible risks and threats that might affect the operational cycle of an organization. The result of this process is that strategies and plans of prevention, correction and mitigation are created, allowing the organization to respond. At the Health Care Provider (HCP) level, it is necessary to manage health alerts related to pharmaceuticals and medical devices in which quality defects and conditions of use have been found that can generate adverse events and have detrimental effects to the well-being of patients. It is also important to consider the integration of the supply chain from the first echelon (Manufacturers) to the last (HCPs); this integration will facilitate traceability and process efficiency along the entire supply chain.

In conjunction with manufacturers and distributors, HCPs are obligated to respond to safety alerts issued by regulators. In Colombia, the National Institute for Drug and Food Surveillance (INVIMA its acronym in Spanish) is the entity in charge of issuing Recalls, Security Reports, Alerts, and Thefts (RSRAT), both national and international. This is done through the joint monitoring of the websites of health agencies from France, the United Kingdom, the United States, Spain, Canada, Brazil and Australia [1]. Other sources of alerts include reports from manufacturers and distributors and queries resulting from reports of adverse events presented by HCPs in the National Pharmaco-surveillance Network (NPN) and National Techno-surveillance Network (NTN), which were created by the INVIMA in 2012. Tables 1 and 2 present historical data from the monitoring of drug and medical device alerts, respectively. This information highlights the fact that in Colombia approximately 50 alerts per month have to be managed.
Table 1. Number of RSRAT alerts of medical devices monitored in 2015

\begin{tabular}{lll}
\hline Medical Devices & \multicolumn{2}{c}{ January - December 2015 } \\
\hline Type & Issued & Apply to Colombia \\
Alerts (A) & 40 & $21(77.5 \%)$ \\
Security Reports (SR) & 320 & $205(64.06 \%)$ \\
Recalls (R) & 93 & $75(80.64 \%)$ \\
Thefts (T) & NA & 64 \\
\hline
\end{tabular}

Table 2. Monitored from

\begin{tabular}{cccc}
\hline \multicolumn{2}{c}{ Number of alerts } & \multicolumn{2}{c}{ Nov 2015 to Jun 2016 } \\
\hline Period & & Recalls (R) & $\begin{array}{c}\text { Security Reports } \\
\text { (SR) }\end{array}$ \\
& Issued & Apply to Colombia \\
Nov-Dec 2015 & 34 & $14(41 \%)$ & 4 \\
Jan-Feb 2016 & 124 & $108(87 \%)$ & 21 \\
Mar-Apr 2016 & 71 & $45(63 \%)$ & 2 \\
May-Jun 2016 & 67 & $33(49 \%)$ & 12 \\
\hline
\end{tabular}

The issue and management of RSRAT alerts is immersed in hospital logistics and is of vital importance within patient safety policies due to the frequency with which alerts are issued and their unpredictability. The goal is to perform rapid alert management in order to minimize patient exposure time, prevent possible adverse events and provide timely treatment to those affected. Tables 3 and 4 present recent high profile cases related to RSRAT alerts of drugs and medical devices. These problems justify the importance of having an effective and efficient system for collecting products that have been identified as potentially hazardous to public health, as well as diffusion of related information as well as training among the personnel who use them. In the case of large HCPs, logistics become even more complicated due to the large number of products being handled, the number of patients being treated and the high level of risk involved. However, in spite of the 
regulations regarding the traceability required to respond to RSRAT alerts, in Colombia there is no public evidence about the complete fulfillment of alerts by all members of the supply chain. Therefore, operations carried out by the HCPs in these cases are unknown.

Additionally, in a 2015 study carried out by made by the INVIMA, which evaluates the level of implementation of Institutional Pharmacovigilance Programs in various HCPs in the country, $0 \%$ compliance was discovered regarding the documentation of periodicity in the review of alerts published by the INVIMA in 15 HCPs in Chocó and Valle del Cauca [2]. Due to these findings, and in the interest of making a documented academic contribution to the literature about hospital logistics operations in the region -a subject on which little work has been done to date-, this study seeks to characterize the practices that are carried out in local HCPs in Santiago de Cali, Valle del Cauca. This with the aim of identifying strengths and weaknesses, as well as opportunities for and barriers to the recalls management process at the HCP level.

Table 3. Selected high profile pharmaceutical safety incidents

\begin{tabular}{|c|c|c|c|}
\hline Pharmaceutical & Year & Type & Description \\
\hline $\begin{array}{l}\text { Molfethyl } \\
\text { Micofenolate, } \\
\text { Sodium } \\
\text { Mycophenolate }\end{array}$ & 2008 & Alert & $\begin{array}{l}\text { The FDA reports children } \\
\text { born with serious congenital } \\
\text { deformities including } \\
\text { microtia, cleft lip and cleft } \\
\text { palate following exposure to } \\
\text { mycophenolate mofetil during } \\
\text { pregnancy. This drug is used in } \\
\text { the treatment of autoimmune } \\
\text { diseases. }\end{array}$ \\
\hline Clozapine & 2011 & Alert & $\begin{array}{l}\text { Risk of occurrence of } \\
\text { potentially fatal complications, } \\
\text { such as intestinal obstructions, } \\
\text { ischemia and perforations } \\
\text { due to the Clozapine. This } \\
\text { drug is used to treat severe } \\
\text { schizophrenia. }\end{array}$ \\
\hline Mercaptopurine & 2011 & $\begin{array}{l}\text { Security } \\
\text { Report }\end{array}$ & $\begin{array}{l}\text { The FDA reported on a rare } \\
\text { cancer in white blood cells } \\
\text { mainly in adolescents and } \\
\text { young adults on treatment for } \\
\text { Crohn's disease and ulcerative } \\
\text { colitis with Mercaptopurine. }\end{array}$ \\
\hline $\begin{array}{l}\text { Sildenafil, } \\
\text { Tadalafil, } \\
\text { Vardenafil }\end{array}$ & 2014 & $\begin{array}{l}\text { Security } \\
\text { Report }\end{array}$ & $\begin{array}{l}\text { Potential risk of sudden } \\
\text { hearing loss and potential risk } \\
\text { of sudden decrease or loss of } \\
\text { vision. These drugs are used } \\
\text { for erectile dysfunction. }\end{array}$ \\
\hline Ondansetron & 2014 & Recall & $\begin{array}{l}\text { The Institute of Public Health } \\
\text { of Chile (ISP) has reported } \\
\text { on the microbiological } \\
\text { contamination by Sarocladium } \\
\text { kiliense in two batches of the } \\
\text { drug ondansetron. This is used } \\
\text { in the treatment of nausea } \\
\text { and vomiting induced by } \\
\text { chemotherapy and radiotherapy } \\
\text { in patients with cancer. }\end{array}$ \\
\hline
\end{tabular}

\section{LITERATURE REVIEW}

\section{A. Background}

At the end of the last decade, the United States implemented the unique identification for pharmaceuticals and medical devices. In addition, health care providers were connected with the U.S. Food and Drug Administration (FDA) through an internet platform. Through this network, alerts issued for pharmaceuticals and devices are communicated to all members. Thanks to this, the recall process was reduced by approximately 40 days [3].

Table 4. Selected high profile medical device failures

\begin{tabular}{|c|c|c|c|}
\hline Medical Device & Year & Type & Description \\
\hline $\begin{array}{l}\text { PIP Breast } \\
\text { Implants }\end{array}$ & 2012 & Recall & $\begin{array}{l}\text { Index of breakage above } \\
\text { average. Disruption of implants } \\
\text { can cause severe pain, changes } \\
\text { in the shape of the breast, } \\
\text { inflammation, hardening, } \\
\text { persistent secretion, shrinkage } \\
\text { of the skin, capsular contracture, } \\
\text { leakage of silicone into tissues, } \\
\text { and formation of mass around } \\
\text { the implant. A thorough medical } \\
\text { evaluation should be performed } \\
\text { prior to removal. }\end{array}$ \\
\hline $\begin{array}{l}\text { HEARTSTART } \\
\text { Defibrillator }\end{array}$ & 2014 & Alert & $\begin{array}{l}\text { It was found that the defibrillator } \\
\text { may not deliver adequate power } \\
\text { or the discharge cannot be } \\
\text { administered. }\end{array}$ \\
\hline $\begin{array}{l}\text { MEDPOR } \\
\text { Surgical } \\
\text { Implants }\end{array}$ & 2015 & Recall & $\begin{array}{l}\text { The manufacturer informs that } \\
\text { facial implants can present } \\
\text { problems of component rupture } \\
\text { and incorrect location. }\end{array}$ \\
\hline $\begin{array}{l}\text { STRYKER } \\
\text { Implant Hip } \\
\text { System }\end{array}$ & 2016 & Recall & $\begin{array}{l}\text { The manufacturer has detected } \\
\text { that the hip implants do not meet } \\
\text { the required levels of sterility } \\
\text { assurance, which may lead } \\
\text { to potentially serious adverse } \\
\text { events occurring in patients. }\end{array}$ \\
\hline
\end{tabular}

Additionally, in 2013, the ECRI Institute developed a tool for hospitals: Alerts Tracker Automach. This system performs an automatic search for products that are subject to a recall in the hospital inventory information system and notifies the corresponding staff [4].

Among the documented cases is that of the Duke University Hospital (DUH), where the Senior Recall and Response Team (SRRT) was formed. This team is responsible for alert response processes and impact assessment in patients [3]. When alerts do not compromise ongoing processes, the information is sent to the personnel, products are removed and documentation is made. For the opposite case, in addition to the aforementioned actions, the SRRT obtains the list of patients and clinic processes involved in order to evaluate risks and alternatives, and to disseminate the alert between physicians, patients, and patient safety committees. In this instance, the alert remains in a monitored state, but 
it becomes closed when all staff have responded with the required actions, all exposed patients have received clear and consistent communication about the alert, and health care services were provided [3].

Besides, in 2014, an exploration of recalls in the US pharmaceutical industry documented further actions that add value to the process and shorten the time for closing the alert. These include unique coding; standardization of operations; good communication and joint work between members of the supply chain; the use of means of rapid dissemination of information; and consumer awareness of the search for information about whether the product that the patient consumes or uses is part of a recall [5].

In Colombia, Law 100 of 1993 brought about the creation of the General System of Social Security (GSSS), which led to the implementation of several structural changes as a consequence. Meanwhile, it was necessary to manage reliable and timely information between the actors involved in the healthcare system. In response, Resolution 0255 stipulated the mandatory adoption of the Unique Medicines Code (UMC) as a single reporting and traceability code for the GSSS. This connects the file number with the AnatomicalTherapeutic Classification code (ATC), international common denomination, pharmaceutical form, composition, route of administration and commercial presentation. Later, in June 2012, the Ministry of Health initiated the process of Semantic Standardization for the national identification of medical devices. A year later, Resolution 2535 of 2013 indicated that beginning on July 11 of that same year products that were granted or renewed sanitary registration and whose use and destination is the GSSS should obtain their respective Unique Identification of Medical Devices (UIMD).

\section{B. Information technologies and unique identifiers}

For each recall alert issued by the INVIMA in response to the detection of a pharmaceutical or medical device that does not comply with the established quality parameters and their respective legislation, it becomes necessary to implement a system of timely identification of the product. Therefore, traceable identification of pharmaceuticals and medical devices is key in the recall processes, accompanied by an integrated information system that connects all the agents that are part of the chain of production, distribution and consumption of pharmaceuticals and medical devices at the national level. Some benefits of implementing unique coding for these products were published in the International Pharmaceutical Industry report (2014): ensuring compliance with government and industry regulations, reducing the risk of patient exposure, decreasing recall process time, and reducing the risk of incomplete information [5].
Currently, to be able to store encrypted data about pharmaceuticals and medical devices, it is necessary to use Auto Identification and Data Capture (Auto ID DC) technologies in order to avoid the possibility of human errors when performing the manual registration of these products. In Colombia, an organization called Logyca, a member of the global GS1 supply chain standardization network, provides connectivity solutions to companies in different sectors of the country by making their product information visible through identification and communication standards [6]. Recalls management is an important process to be analyzed in order to identify the potential use of GS1 Data Standards, which are unique, unambiguous identifiers for product and location identification not only inside HCPs, but also across the entire supply chain [7]. The GS1 code includes the international product identification, batch number, expiration date and serial number. The Datamatrix coding system is promoted in Colombia as the standard; this system is a two-dimensional code that allows for the generation of a large volume of information in a very small format with a high reliability of reading [8].

\section{Methodology}

In this study, a SWOT (Strengths, Weaknesses, Opportunities, and Threats) analysis was developed in order to identify internal and external factors that affect the recalls management process at the HCP level. The analysis was supported by a literature review and fieldwork associated with the characterization of the recalls management process in various institutions which, due to confidentiality issues, cannot be disclosed. The information related to the fieldwork will be treated in a generic way so that the participants cannot be identified. Given the amount of information required, it was determined that interviews were the best instrument for obtaining the characteristics of the process. In this way, it was possible to collect the information of each $\mathrm{HCP}$, which specifies how they proceeded before, during and after a RSRAT alert, including activities carried out as well as product and information flows.

\section{A. Internal aspects}

The identification of internal aspects was performed based on the comparison of the generic aspects of the recalls management process which was configured based on the information gathered in the fieldwork (interviews) and the process described in [3], which is presented in Fig 1. Interviews related to generic aspects were divided into five sections according to the steps within the recalls management process. The first step, 
pharmaceuticals and medical devices identification and traceability, was intended to inquire about the process of product registration, the code used to identify them, which information is saved, how the distribution is carried out through the different areas, and how the patientproduct relationship is made. The second section, alerts notification, aims to investigate the alert sources used and how the information is circulated inside the HCP. The third section, alert response, inquires about how the HCPs locate the products involved, the actions executed for each type of alert and which monitoring indicators are used. The fourth section, oversight of patients, inquires about how the patients who have been exposed to a product on alert are identified, and the response of the patient safety programs inside the HCPs. Finally, the fifth section, alert closing, aims to answer how the alert closing is defined, the time expended and how staff performance is measured.

Based on the information obtained from the local fieldwork and taking into consideration the practices from an institution in a country at the forefront of the subject [3] strengths and weaknesses were established for the aspects characterized above. To this end, strengths were defined as the adoption by the HCP of a process or resource that favors the coordinated and efficient management of RSRAT alerts. At the same time, weaknesses were defined as the lack of a process or resource that allows for effectiveness in the comprehensive response to alerts.

\section{B. External aspects}

External aspects were identified by comparing the existing processes to the current national regulation and international best practices as described in [9]. Based on this information, opportunities for improvement were defined as possible actions to be carried out based on compliance of certain aspects denoting the possibility to increase the capacity to meet the requirements or improve the performance of the RSRAT alert response process. Also, barriers - as threats - were identified as context elements that impede compliance with regulations.

\section{RESULTS}

\section{A. Internal Aspects}

At the beginning of the study, the authors found that inside the HCPs, personnel in charge of logistics operations related to pharmaceuticals and medical devices are pharmaceutical chemists and biomedical engineers. The former are in charge of pharmaceuticals, consumable and implantable medical devices while the latter are in charge of biomedical equipment. Because pharmaceutical chemists are also the primary managers of the RSRAT alerts, the first task of the study was to interview them. However, biomedical engineers and sterilization staff were also included. It was discovered that professionals in both fields could benefit from knowing and managing logistics and supply chain concepts, which in some cases were not recognized.

About pharmaceuticals and medical devices traceability, two scenarios were identified. On the one hand, there are some HCPs that have sufficient resources to acquire the needed technology for gathering and storing product tracking information (e.g. lot and serial number). This is possible because as products arrive to the HCP, they are separated, repackaged, relabeled with internal Datamatrix codes and registered in the respective information systems. Additionally, products are moved both physically and virtually through the different areas, with their identification data being saved with the medical records of the patients in whom they were used. On the other hand, the remaining HCPs, have not had such development and therefore have difficulties storing product tracking information. At these institutions, only pharmaceuticals contained in pills and some medical devices are separated, repackaged and relabeled. Products are also registered in the information system, but tracking information such as lot and serial number is not registered for medical devices. Additionally, these HCPs have traceability at the patient level in hospitalization area only. It was also found that the majority of the HCPs use an internal code rather than the SDC and the UIMD to identify products that are stored.

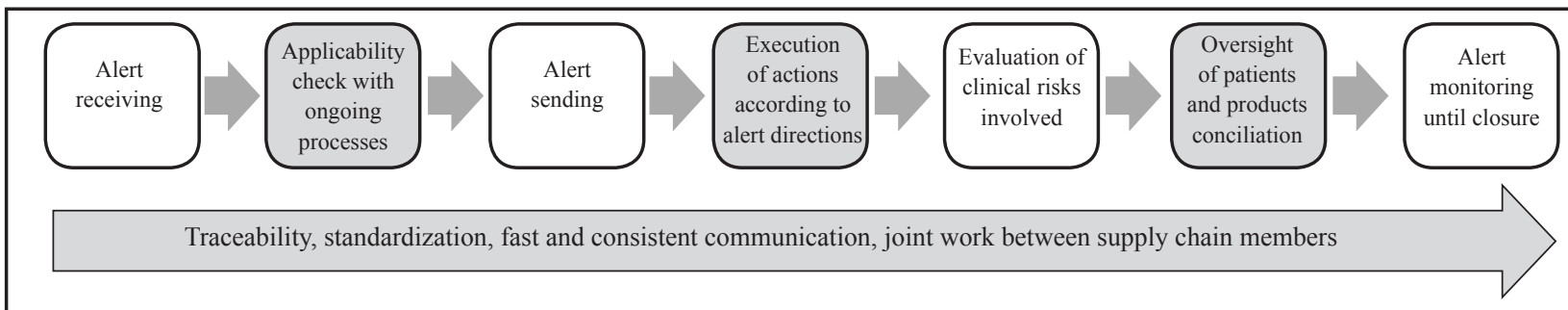

Fig 1. Main steps of the alerts management process. Adapted from [3] 
This means that there is noncompliance with the regulation and that more codes are created in addition to the sanitary registry, those assigned by the manufacturer, and those required by law, among others. Evidently, traceability within the supply chain and within the GSSS is hampered.

The authors inquired about the interaction of the alerts managers with different sources of alerts notification. On the one hand, the most visited web pages are INVIMA and FDA. Commonly, personnel in charge of alerts search for online alerts daily. However, it was found as a good practice to have web subscriptions to ECRI, INVIMA and other entities in order to receive direct emails with issued alerts. The staff of the majority of the HCPs are unaware of the fact that the INVIMA offers this service for free. On the other hand, since HCPs remain relatively current with RSRAT alerts, supplier reports usually arrive after a response has already been issued. Moreover, there is no communication between HCPs, however there is an informal messenger group of about 50 pharmaceutical chemists where alerts are sometimes shared.

When the alert response starts, the first action that the manager has to execute is to investigate whether the product has entered the HCP. As was previously mentioned, few HCPs register complete information about products and can locate them in any area; this is the reason that staff have to physically look for products area by area. Additionally, as some HCPs do not save tracking information outside the distribution center, the person in charge of the alert has to ask for a report of product inventory movements that may reveal the possible location and quantity of products on alert that remain inside the HCP. Once the alert manager verifies that an open alert applies to the HCP's operations, the diffusion media used among the staff is institutional email. It was further identified as a good practice that within a HCP, the staff shares the information about the alert in the different areas of the HCP once per shift. When there is a recall, personnel are assigned to gather the products, place them under quarantine and remove them from the information system. When there is a security report or an alert, actions established by the publication are executed. However, when it comes to a theft alert, it is rare that a HCP takes action on the matter by warning the purchasing department and the receiving warehouse. It was found that the majority of the HCPs do not even know of the existence of this type of alert. Finally, in spite of the different operations needed, no HCP uses monitoring indicators when an alert response is in an ongoing state at the institution.

Regarding oversight of patients, one of the HCPs interviewed had patient security programs and an ethics committee which oversees patients who have been in contact with products on alert, either when it is known for certain or is even suspected. As can be expected, HCPs where there is no traceability at the patient level must invest greater efforts to identify adverse events. However, when a recall is for implantable medical devices, HCPs are required to save complete information about both product and patient. Despite this, no HCP had fully reliable identification data for osteosynthesis material. At this point, the authors also found that, unlike in US institutions, the culture inside the HCPs studied does not conceive as convenient to communicate the alert to the patients. Even if a patient has been exposed to a product on alert or has experienced adverse events related to it, he or she is neither warned nor informed about it. The only way that there is communication with the patients is in cases when a medication change is required.

The majority of alert closings coincide with the diffusion of information. However, in the case of a recall, the alert is closed when all the involved products have been returned to the supplier. Inside the HCPs studied, it was found that not all the RSRAT alert managers have defined when the different types of alerts are closed. They do not even know how much time on average is expended of the process. Documentation about recalls is rarely consolidated, and few HCPs report adverse events to the national surveillance networks. Also, it was identified as a good practice to have periodic meetings where actions executed through the alert management are shared.

\section{B. External Aspects}

From the analysis performed in the previous section, opportunities for improvement were identified not only for the HCPs, but also for the INVIMA, manufacturers and laboratories, as the recall process is conceived of not only as a process at the last echelon of the supply chain but as an integral part of supply chain traceability. Opportunities are presented in three sections: traceability, which refers to weakness identified in coding and tracking information management; communication with regulatory entities, which is related to alerts notification and adverse events reports; and alert management, that gathers possible improvements related to alerts response, oversight of patients and alert closing. Finally, general restrictions and barriers to the enhancement of the process are presented.

On one hand, regarding the identification codes used inside the HCPs, it was found that even with an internal code it is possible to enact an effective response. Further, codes that include traceability information such as lot and serial number are beneficial not only for timely alerts response, but also for dispending and billing, among other processes. Then, the GS1 Data Standard and the characteristics of Datamatrix code emerge as an ideal alternative in this context. On the other hand, traceability 
is accompanied by the registration of the movement and use of products. These operations are facilitated by the implementation of an integrated information system, equipment for creating and reading codes, and several computers available to register the products in medical records. Nonetheless, it was also found that even with few resources and good management of excel sheets, it is possible to obtain acceptable traceability. In addition, it is relevant to include the level of commitment to traceability as an indicator in the search and selection of providers of pharmaceuticals and medical devices.

Regarding the communication with regulatory entities, a subscription to INVIMA is crucial for receiving issued alerts. By doing this, daily online searches are unnecessary. At the time this study was undertaken, it was known that the service was working, however the subscription process was not yet available. Moreover, while subscriptions to international regulation entities may be costly, these services can be worthwhile in order to gather updated information about medical device use and maintenance, as the majority of them are imported. Additionally, in spite of the fact that the NPN and the NTN seek to support the HCPs in the prevention of adverse events, the information generated by these networks are currently being underused. Report formats are tedious to fill out, HCPs are not required to fill them out, and the networks work for sending but not for sharing information. While this situation improves, it is important to be subscribed in order to be informed about the guidelines and forms, as well as to become accustomed to gradually reporting adverse events.

On the one hand, staff support and cooperation is indispensable at the moment of acting previous to an alert. The immediate alert management and future use of products involved depends on the sensitization to and the training given to the staff in patient safety. Electronic and direct communication means can be considered in order to obtain a quick response, to guarantee that an alert was received and to seek that the staff better remember the information. On the other hand, as traceability is achieved, there will be greater certainty about patients at potential risk. Therefore, oversight can be extended to patients who are outside the facilities. Additionally, it is important to raise awareness among patients about alerts. Concise communication with them is vital, at least in cases when an adverse event has occurred. In this context, the manufacturers' responsibilities should be included in order to mitigate the effects of the event on their business image. Finally, in order to have effective and consistent alert management, it would be beneficial to measure monitoring indicators. This is being proposed with the aim of defining the closure of the alert, measuring staff performance and reporting the alert effects to the regulatory entity. Of course, the final objective is to continuously improve alert or recalls management.

The first barrier that HCPs can encounter in applying new information technologies is that it implies a high investment in equipment acquisition, software development and procurement, qualified personnel, and database space, among others. These resources may not be accessible in the short or medium term for most institutions. The second obstacle is that there is currently no consensus in the regulations of the General System of Social Security with respect to the coding that must be used throughout the supply chain in order to guarantee the proper traceability of the products. The third obstacle is the weakness of regulatory institutions in guaranteeing the traceability compliance of manufacturers and laboratories. This generates little or no interest in investing in efforts to facilitate the tracking of pharmaceuticals and medical devices. Consequently, HCPs are forced to perform the tedious and repetitive manual processes of re-labeling and dispensing for each incoming product.

\section{Conclusion}

After completing this study, the main conclusion reached is that HCPs have been investing isolated efforts in traceability in order to guarantee patient safety and quality of service within their walls, while there is a lack of cooperation by manufacturers and laboratories. While institutions are required by law to guarantee the traceability of their products, this is far from being a priority. Additionally, despite regulations requiring the use of SDC and the semantic standard, they are not used by the INVIMA in alert publications and do not contain tracking information. Numerous codes have been created: manufacturers' bar codes, the sanitary registry, SDC or the sematic standard, and that used inside the HCP. As has been noted previously, HCPs can respond effectively with an internal code, but an international standardized code is needed in order to achieve traceability throughout the supply chain. Logistics and supply chain process integration is an important topic for professionals in charge of supply chain related processes within the healthcare supply chain; having the knowledge and tools to improve these processes can benefit not only the institution, but also the healthcare supply chain as a whole.

The fact that HCPs act with the same urgency to the RSRAT alerts received can be considered positive, but it is of concern that HCPs are not usually aware of the severity of the alerts and the adverse events that their patients may be facing. This is one of the reasons that reporting and sharing in national networks is crucial to the prevention, 
identification and treatment of adverse events associated with an alert. Further, nowadays it may be easy for HCPs to provide a quick response due to the number of alerts, but risk classification is also used in US institutions because they have to manage two to three times more alerts and more products. Therefore, as medical technology advances and there are continually more products to be in charge of, it will be necessary to differentiate response protocols according to risk level.

Addressing RSRAT alerts not only seeks to improve patient safety, it also helps to provide better treatment, as when a drug use enhances the effect of another drug. Similarly, the fact that there are internal regulations about acquired product does not imply that purchasing processes result in the acquisition of stolen devices. Then, surveillance through theft alerts management would be useful in preventing adverse events derived from modified devices. Personnel and patient awareness about alerts needs to be heightened. Besides, the joint use of electronic and direct communication media and the training and sensitization about alerts would be useful for providing a quick and consistent response. For patients, it is important to emphasize the importance of keeping medical device identification and searching for alerts about the products that they use in order to seek early medical care in the event of being exposed to a product on alert. However, this responsibility lies jointly with the INVIMA.

Finally, this study also makes evident the need for manufacturers and laboratories to be aware of the consequences of alerts in order to ensure the provision of relevant health services to affected patients, and thus to mitigate the effects on their corporate image. An integrated vision of the supply chain accounting for all echelons within it is required. Additionally, by law, it is mandatory that these companies have protocols for collecting products on alert with traceable information about them, a topic in which they have a wide field of work. Regarding INVIMA, aside from the need to strengthen its surveillance activities, it is recommended that it continue working on the building of the NPN and the NTN in order to fulfill the objectives for which they were created.

\section{ACKNOWLEDGMENT}

Authors are very grateful to the staff at each HCP who provided their time, knowledge and experience for the development of the study.

\section{REFERENCES}

[1]. INVIMA. (2016, Febrero). GESTIÓN DE INFORMES DE SEGURIDAD - ALERTAS - RECALLS E HURTOS (RSRAT). Retrieved from Instituto Nacional de Vigilancia de Medicamentos y Alimentos: https://www.invima.gov.co/gesti\%C3\%B3n-deinformes-deseguridad-alertas-recalls-e-hurtos-RSRAT

[2]. INVIMA. (2015, Abril 12). Reporte de Informe de Seguridad, Alerta, Retiro Producto del Mercado o Hurto por parte de Importadores, Fabricantes y Distribuidores de Dispositivos Médicos. FORMATO REPORTE DE INFORME DE SEGURIDAD, ALERTA, RETIRO PRODUCTO DEL MERCADO O HURTO (RSRAT), POR PARTE DE IMPORTADORES, FABRICANTES Y DISTRIBUIDORES DE DISPOSITIVOS MÉDICOS PARA DISPOSITIVOS MÉDICOS . Colombia: INVIMA.

[3]. Frush, K., Pleasants, J., Shulby, G., Hendrix, B., Berson, B., Gordon, C., et al. (2009). Blending Technology and Teamwork for Successful Management of Product Recalls. Academic Medicine, Vol. 84, No. 12, 1713-1718.

[4]. ECRI Institute. (08 de Agosto de 2013). ECRI Institute System is First to Automatically Find Recalled Products in a Hospital's Inventory. Recuperado el 20 de Febrero de 2016, de ECRI Institute: https://www.ecri.org/press/Pages/AutomatchAutomatically-Find-Recalled-Products.aspx

[5]. Shewale, S. D., Chavan, M., \& Parekh, S. S. (2014). Pharmaceutical Product Recall: Lesson Learned. INTERNATIONAL PHARMACEUTICAL INDUSTRY, 16-23.

[6]. GS1 Colombia. (2015, Julio 14). Nosotros GS1 Colombia. Retrieved from GS1 Colombia: http://www.gs1co.org/nosotros/ gs1 colombia.aspx

[7]. Buyurgan, N., Rardin, R., Jayaraman, R., Varghese , V., \& Burbano, A. (2011). A novel GS1 Data Standard Adoption Roadmap for Healthcare Providers, International Journal of Healthcare Information Systems and Informatics, October December 2011 (41-58)

[8]. Integro Technologies. (2014, Octubre 15). GSI DATA MATRIX EXAMPLE WITH GTIN. Retrieved from Integro Technologies: http://www.integro-tech.com/machine-vision/ gs1-data-matrixexample-with-gtin/

[9]. Marucheck, A., Greis, N., Mena, C., \& Cai, L. (2011). Product safety and security in the global supply chain: Issues, challenges and research opportunities. En A. Marucheck, N. Greis, C. Mena, \& L. Cai, Journal of Operations Management (págs. 702-720). 